\title{
Evidence of an Altered 5'-Monodeiodinase for Thyroxine in the Liver of the Fetal Rabbit
}

\author{
MARGOT SEGALL-BLANK, ALAN BALSAM, AND SIDNEY H. INGBAR ${ }^{(29)}$ \\ Charles A. Dana Research Institute and Harvard-Thorndike Laboratory of Beth Israel Hospital, Department of \\ Medicine, Beth Israel Hospital and Harvard Medical School, Boston, Massachusetts, USA
}

\begin{abstract}
Summary
To explore further the factors that underly the deficient generation of $3,5,3^{\prime}$-triiodothyronine $\left(T_{3}\right)$ from thyroxine $\left(T_{4}\right)\left(T_{3}\right.$-neogenesis) in fetal liver, studies were performed in homogenates and subcellular fractions of liver from pregnant rabbits and their corresponding fetuses. In whole homogenates, $\mathbf{T}_{3}$-neogenesis (percentage added $T_{4}: 50 \mathrm{mg}$ protein) during $3 \mathrm{hr}$ incubations of specimens from fetuses proceeded at a much slower rate $(1.7 \pm 0.5$, mean \pm S.D.) than in specimens from the corresponding does (1.4 \pm 5.3). Dithiothreitol (DTT, $20 \mathrm{mM}$ ), a known stimulant of $T_{3}$ neogenesis, did not significantly alter the activity of fetal specimens $(2.6 \pm 1.3)$, but significantly increased activity in those obtained from does $(18.2 \pm 7.4)$. To investigate the basis for these differences, additional experiments were performed in which microsomal and cytosolic fractions from fetal and maternal livers were variously mixed and $T_{3}$-neogenesis was assessed in the presence and absence of DTT. Activity of fetal microsomes was consistently less than in maternal microsomes, regardless of the source of the cytosols with which they were incubated. Further, mixtures containing fetal microsomes were not stimulated by DTT, whereas those containing maternal microsomes were. In addition to this evidence of an abnormality with respect to the fetal enzyme, evidence was obtained of a concomitant abnormality in fetal cytosol fractions. Thus, $T_{3}$-neogenesis by maternal microsomes was consistently greater when incubated with maternal cytosol than with fetal cytosol, presumably owing to lesser support of $\mathbf{T}_{3}$ neogenesis by cofactors known to be present in cytosol. Additional evidence of an abnormality in the microsomal enzyme of the fetus was obtained in studies of the kinetics of $T_{3}$-neogenesis. In the presence of DTT, derived values for the $K_{m}$ of the fetal enzyme were approximately 10-fold higher than were those for the maternal enzyme $\left(5.9 \times{ }^{-5}\right.$ and $\left.7.1 \times 10^{-6} \mathrm{M}\right)$.
\end{abstract}

The studies suggest that the defective generation of $T_{3}$ from $T_{4}$ seen in fetal liver from other species is also present in the liver of the fetal rabbit. Lower activity in the fetal liver is due in part to a lesser activity of cytosolic cofactors, but mainly to an abnormality in the $T_{3}$-generating enzyme, reflecting either a lower concentration of enzyme, a lesser responsiveness to stimulatory cofactors, or a combination of the two.

\section{Speculation}

The enzyme in fetal liver that converts thyroxine to $3,5,3^{\prime}$ triiodothyronine behaves differently from that in maternal liver with respect to its affinity for substrate and its response to stimulatory sulfhydryl cofactor. Fetal enzyme may be an isozymic variant of the adult enzyme, as has been reported for other hepatic enzymes. The relation between fetal and maternal enzymes may be analogous to that which exists with respect to enzymes of normal and malignant tissue.

It is clear from a variety of studies that the peripheral $5^{\prime}$ monedeiodination that generates $3,5,3^{\prime}$-triiodothyronine $\left(T_{3}\right)$ from thyroxine $\left(\mathrm{T}_{4}\right)$, a process we have termed $\mathrm{T}_{3}$-neogenesis, proceeds at a generally slower rate during fetal life that it does at some time after birth or during adult life (9, 12, 18, 19, 21, 22). Apparently, this difference occurs quite widely among the vertebrates, since it has been demonstrated in several mammalian species $(9,15,19$. $21,25)$, including man $(8,12,23)$, as well as in the chick embryo (4).

The biochemical factors responsible for this difference have mainly been explored in studies of $\mathrm{T}_{3}$-neogenesis in vitro, most often in preparations of liver, but somewhat contradictory conclusions have been drawn. Studies in the sheep have suggested that a deficiency of sulfhydryl cofactor is largely responsible for the lower rate of $\mathrm{T}_{3}$-neogenesis in liver homogenates from fetuses than in those from adults, since this difference was no longer apparent when homogenates were enriched with dithiothreitol (DTT) (25). On the other hand, in the liver of the fetal rat (14) or chick (4), addition of reduced glutathione or of DTT has failed to abolish the difference between the immature and mature liver, pointing strongly to a variance in the concentration or properties of the fetal enzyme. To explore this matter further, we have studied the fetal rabbit so that experience with still another species could be obtained.

\section{MATERIALS AND METHODS}

\section{ANIMALS AND TISSUE PREPARATIONS}

Pregnant New Zealand White rabbits and their fetuses were sacrificed on their 28th gestational day by a rapid injection of a lethal dose (150 to $200 \mathrm{mg}$ ) of phenobarbital. The fetuses were immediately delivered by uterotomy. Whole livers were taken from fetuses, and a sample of liver was also taken from the corresponding doe. From this point onward, fetal and maternal tissues were processed separately, but concomitantly, and in an identical manner. Tissues were cooled by keeping them on crushed ice. Each liver was blotted dry and divided in half, and the halves weighed, after which fetal livers were pooled. Two types of homogenate were then prepared. The first, to be used in studies of whole homogenates, was prepared by homogenizing similar weights of maternal and pooled fetal livers in $0.15 \mathrm{M}$ phosphate buffer $(1: 3, w: v) \mathrm{pH}$ 7.4. These homogenates were always used for experiments on the same day that they were prepared.

The second type of homogenate was used for the preparation of crude microsomal and cytosolic fractions. Here, similar weights of pooled fetal or maternal liver were homogenized (2:5, w:v) in 0.25 M sucrose: $0.05 \mathrm{M}$ phosphate buffer ( $\mathrm{pH} 7.4$ ), and the homogenates centrifuged at $10,000 \times g$ for $15 \mathrm{~min}$ at $4^{\circ} \mathrm{C}$. The pellet was discarded and the supernatant was then centrifuged at $105,000 \times$ $g$ for $60 \mathrm{~min}$. The resulting supernatant (cytosolic fraction) was separated from the crude microsomal pellet, and the latter was washed twice by resuspension and centrifugation in phosphate buffer. The pellets derived from $3 \mathrm{~g}$ of liver tissue were then resuspended in $2 \mathrm{ml}$ of phosphate buffer and were stored frozen at $-70^{\circ} \mathrm{C}$, as were the cytosols, until they were used in experiments 
within 1 to $3 \mathrm{wk}$. Control experiments revealed that these fractions could be stored for at least one month without loss of activity,

\section{INCUBATIONS}

In experiments with whole homogenates, $2 \mathrm{ml}$ aliquots were enriched with $10 \mu \mathrm{l}$ of a solution of ${ }^{125} \mathrm{I}$-labeled $\mathrm{T}_{4}$ (specific activity, 60 to $70 \mu \mathrm{Ci} / \mu \mathrm{g}$ ). containing $40 \mathrm{ng}$ of $\mathrm{T}_{4}$ and approximately 2.4 $\mu \mathrm{Ci}$ of ${ }^{125} \mathrm{I}$. Homogenates were then incubated for $3 \mathrm{hr}$ at $37^{\circ} \mathrm{C}$ under $\mathrm{N}_{2}$, both with and without $20 \mathrm{mM}$ DTT. Several kinds of control vessels, similarly enriched, were prepared and incubated under the same conditions. One was devoid of tissue, one contained boiled homogenate, and the third, which contained fresh homogenate, was kept on crushed ice for $3 \mathrm{hr}$. Incubations were terminated by the addition of outdated blood bank plasma (1:2, $v: v)$. Portions of the reaction mixtures were then frozen for 1 to 3 days before they were uniformly resuspended and analyzed by paper chromatography according to techniques described below.

Experiments were also performed to assess the rate of degradation of added ${ }^{125} \mathrm{I}-\mathrm{T}_{3}$ by homogenates of liver from fetuses and does, with and without added DTT. Methods used were identical to those used in studying the generation of $T_{3}$ from $T_{4}$, except that ${ }^{125} \mathrm{I}_{-} \mathrm{T}_{3}$ (specific activity, 70 to $100 \mu \mathrm{Ci} / \mu \mathrm{g}$ ) was added to homogenates, rather than ${ }^{125} \mathrm{I}_{-} \mathrm{T}_{4}$.

In experiments with tissue fractions, cytosols and microsomal suspensions were thawed at room temperature. Thawed microsomal preparations were recentrifuged at $105,000 \times \mathrm{g}$ for $10 \mathrm{~min}$. The supernatant buffer was discarded and the pellet was resuspended by homogenization in $2 \mathrm{ml}$ of fresh $0.15 \mathrm{M}$ phosphate buffer. To $1.7 \mathrm{ml}$ aliquots of either fetal or maternal cytosols or to $0.15 \mathrm{M}$ phosphate buffer alone, was added either $0.3 \mathrm{ml}$ of the fetal or $0.2 \mathrm{ml}$ of the maternal microsomal suspension. Differing volumes of fetal or maternal microsomal suspensions were added because preliminary analyses had revealed that the protein concentration of the fetal microsomes was approximately two-thirds that in suspensions of maternal microsomes similarly prepared. The resulting mixtures were enriched with $40 \mathrm{ng}$ of ${ }^{125} \mathrm{I}_{-} \mathrm{T}_{4}$, and were incubated with and without DTT for $3 \mathrm{hr}$ at $37^{\circ} \mathrm{C}$ under $\mathrm{N}_{2}$. Control vessels analogous to those used in experiments with whole homogenates were also studied. Reactions were terminated by removing portions of the reaction mixtures and adding them to outdated blood bank plasma (1:2; w:v). These mixtures were then analyzed by paper chromatography.

\section{KINETIC STUDIES}

Two experiments were conducted to evaluate the kinetics of the $5^{\prime}$-monodeiodination of $\mathrm{T}_{4}$ by fetal and maternal liver microsomes. In these studies, $T_{3}$-neogenesis was assessed in microsomes incubated only in buffer, and cytosol was not used. In the first experiment, 100,200,300, and $400 \mu$ l aliquots of fetal microsomes containing approximately $1 \mathrm{mg}$ protein per $100 \mu \mathrm{l}$ were suspended in various volumes of phosphate buffer to yield a final volume of $2.1 \mathrm{ml}$. In the case of maternal microsomes, $200 \mu \mathrm{l}$ aliquots were used. Buffer was enriched with $20 \mathrm{mM}$ DTT and with mixtures of unlabeled and ${ }^{125}$ I-labeled $\mathrm{T}_{4}$ so as to achieve final concentration of $\mathrm{T}_{4}$ ranging between 1.3 and $13 \mu \mathrm{M}$. Microsomal suspensions were incubated for $90 \mathrm{~min}$ in air at $37^{\circ} \mathrm{C}$. Reactions were terminated by the addition of plasma, and mixtures were analyzed by paper chromatography according to techniques described below.

\section{PAPER CHROMATOGRAPHY}

Ten $\mu \mathrm{l}$ of reaction mixture were applied as a spot, together with carrier compounds, $\mathrm{T}_{4}, \mathrm{~T}_{3}$, and iodide, to strips of Whatman no. 3 chromatography paper and were chromatographed in descent, using a hexane:tertiary amyl alcohol:2 $\mathrm{N}$ ammonia solvent system (1:10:11). Iodide was identified by staining dried strips with palladium chloride. Zones corresponding to $\mathrm{T}_{4}$ and $\mathrm{T}_{3}$ were identified by their fluorescence under UV light. The foregoing zones were excised, as were the origins of the chromatograms, and their ${ }^{125} \mathbf{I}$ content separately determined in a scintillation counter. More than $98 \%$ of the total radioactivity recovered from chromatograms, between the origin and the solvent front was contained in four discrete zones representing, respectively, origin material, iodide, $T_{4}$, and $T_{3}$. Values for the percentage generation of labeled products as a fraction of to total ${ }^{125} \mathrm{I}_{-} \mathrm{T}_{4}$ added could thus be calculated. All values for the percentage generation of ${ }^{125}$ I-labeled products were corrected for the percentage contamination by these products in nonmetabolizing control vessels. ${ }^{125} \mathrm{I}-\mathrm{T}_{4}$ and ${ }^{125} \mathrm{I}-\mathrm{T}_{3}$ were approximately $95 \%$ pure before incubation, the major contaminant being ${ }^{125}$ I-iodide, and no significant degradation occurred in tissue-free vessels during the incubation period.

\section{PROTEIN MEASUREMENTS}

Assays for the protein concentration of liver homogenates and suspensions of microsomes were performed according to the method of Lowry et al. (20), using bovine serum albumin as a standard. All results regarding hormone metabolism were standardized to unit protein concentration.

\section{STATISTICAL EVALUATION}

Duncan's Multiple Range test was used to assess the significance of differences obtained among multiple experimental groups (10). In some cases in which results obtained with and without added DTT were compared in otherwise identical preparations, the paired $t$ test was used.

\section{RESULTS}

In all systems studied, only ${ }^{125} \mathrm{I}$-labeled $\mathrm{T}_{3}$, iodide, and small quantities of chromatographically immobile origin material were seen as products of ${ }^{125} \mathrm{I}_{-} \mathrm{T}_{4}$ metabolism. Because the quantity of ${ }^{125}$ I-iodide formed was always greatly in excess of that which could be accounted for by the ${ }^{125} \mathrm{I}-\mathrm{T}_{3}$ generated, it is likely that some pathway(s) other than $5^{\prime}$-monodeiodination of $\mathrm{T}_{4}$ was operative. 5-Monodeiodination of $\mathrm{T}_{4}$ would not have been detected by the appearance of ${ }^{125} \mathrm{I}$-labeled $3,3^{\prime}, 5^{\prime}-\mathrm{T}_{3}$ or $3,3^{\prime}$-diiodothyronine because of their rapid rate of degradation and the relatively long incubation periods used.

\section{WHOLE HOMOGENATES}

Eight experiments were conducted in which $\mathrm{T}_{3}$-neogenesis was studied concomitantly in homogenates of livers from fetuses and from their corresponding dams (Fig. 1). Relative to the quantity of $\mathrm{T}_{3}$ formed (percentage added $\mathrm{T}_{4}$ per $50 \mathrm{mg}$ protein per $3 \mathrm{hr}$ ) in homogenates of maternal liver (14.6 \pm 5.3 ; mean \pm S.D.), $T_{3}$ formation in homogenates of fetal liver was extremely low (1.7 \pm

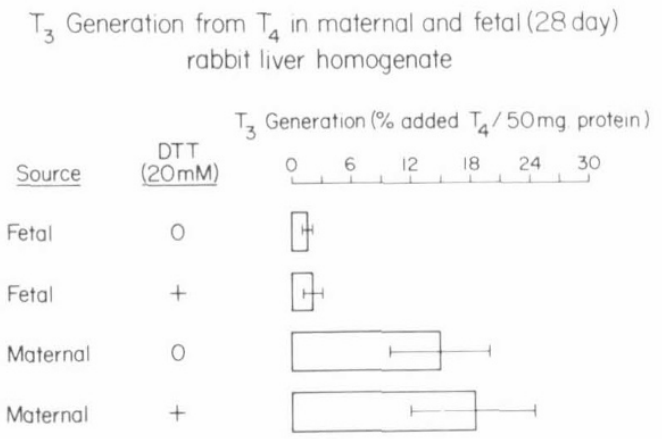

Fig. 1. Generation of ${ }^{125} I-T_{3}$ from ${ }^{125} I_{-} T_{4}$ in homogenates of liver from fetal rabbits ( 28 days of gestation) and from the corresponding does. Results shown represent the mean \pm S.D. of values obtained in eight separate experiments in which maternal and fetal specimens were incubated concomitantly. Values in fetal specimens, with and without DTT, were significantly lower than those in the corresponding maternal specimens $(P<0.01)$, but only in maternal specimens did DTT have a significant stimulatory effect $(P<0.05)$. Statistical analyses were performed using Duncan's Multiple Range Test (25). 
$0.5 ; P<0.001)$. A slight increase in mean $\mathrm{T}_{3}$ formation to $2.6 \pm$ 1.3 was seen when homogenates of fetal liver were enriched with $20 \mathrm{mM}$ DTT, but the difference between values in the presence and absence of DTT was not statistically significant (Fig. 1). In contrast to the findings in fetal liver, $\mathrm{T}_{3}$-neogenesis in maternal liver was significantly increased $(18.2 \pm 7.4 ; P<0.05)$ by the addition of DTT.

Studies with ${ }^{125} \mathrm{I}_{-} \mathrm{T}_{3}$ revealed a relatively slow rate of $\mathrm{T}_{3}$ metabolism in all four experimental groups at the concentrations of $T_{3}$ tested. Percentage degradation of $\mathrm{T}_{3}$ (percentage added ${ }^{125} \mathrm{I}-\mathrm{T}_{3}$ per $50 \mathrm{mg}$ protein per $3 \mathrm{hr})$ in maternal liver $(4.8 \pm 2.5)$ was greater, not less, than in fetal liver $(1.7 \pm 1.0)$. Even in the presence of 20 $\mathrm{mM}$ DTT, this difference between $\mathrm{T}_{3}$ degradation in maternal liver $(12.0 \pm 5.4)$ and fetal liver $(4.7 \pm 1.0)$ persisted. Hence, the greater net generation of ${ }^{125} \mathrm{I}-\mathrm{T}_{3}$ from ${ }^{125} \mathrm{I}_{-} \mathrm{T}_{4}$ in maternal liver than in fetal liver could not be explained by a lower rate of $T_{3}$ degradation in the former.

\section{MIXED MICROSOMAL AND CYTOSOLIC FRACTIONS}

Six experiments were conducted in which all possible combinations of mixtures of microsomal and cytosolic fractions from livers of fetuses and their corresponding dams were studied concomitantly, with and without added DTT (eight experimental groups per experiment) (Fig. 2).

Irrespective of whether reaction mixtures contained fetal or maternal cytosol and of whether or not they contained DTT, $\mathrm{T}_{3^{-}}$ neogenesis in fetal microsomes was significantly lower than that seen in maternal microsomes. The lowest values (percentage added $\mathrm{T}_{4}$ per mg microsomal protein per $3 \mathrm{hr}$ ) were observed in mixtures of fetal microsomes and fetal cytosol without DTT $(0.55 \pm 0.15)$, and values were not increased significantly by the addition of DTT $(0.64 \pm 0.21)$. Mean values in mixtures of fetal microsomes with maternal cytosol $(0.89 \pm 0.59)$ were slightly, but not significantly, higher than those obtained when fetal cytosol was used and also were not significantly increased by the addition of DTT $(1.01 \pm 0.89)$.

Values for the percentage conversion of $T_{4}$ to $T_{3}$ in mixtures of maternal microsomes and fetal cytosol $(1.39 \pm 0.57)$ were significantly higher than those seen in mixtures of fetal microsomes and fetal cytosol $(P<0.05)$, and, unlike those in any mixture containing fetal microsomes, were markedly and significantly increased by the addition of DTT $(3.90 \pm 0.60)$. Further, maternal microsomes, when mixed with maternal cytosol, generated far more $\mathrm{T}_{3}$ $(3.36 \pm 0.94)$ than did the same microsomes when mixed with fetal

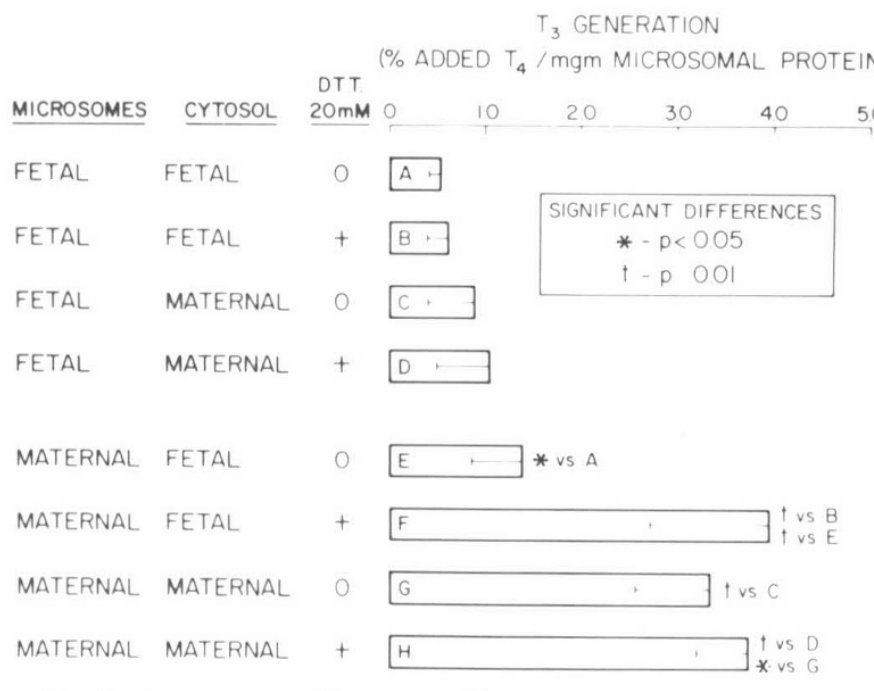

Fig. 2. Generation of ${ }^{125} I-T_{3}$ from ${ }^{125} I_{-} \mathrm{T}_{4}$ in mixtures of hepatic microsomes and cytosol fractions from fetal rabbits and the corresponding does. Results shown are mean \pm S.D. of values obtained in six separate experiments in which all mixtures were incubated concomitantly. Statistical analyses were performed using Duncan's Multiple Range Test (25). cytosol $(1.39 \pm 0.57 ; P<0.01)$. In mixtures of maternal microsomes and maternal cytosol, addition of DTT yielded slightly higher values for $\mathrm{T}_{3}$ generation; this difference was not significant by two-way analysis of variance, but was significant when analyzed by the paired $t$ test $(P<0.05)$. In the presence of DTT, the quantity of $\mathrm{T}_{3}$ generated by maternal microsomes was not significantly affected by whether mixtures contained maternal or fetal cytosol.

\section{KINETIC EXPERIMENTS}

In the suspensions of microsomes in buffer used in these experiments, little or no $\mathrm{T}_{3}$ generation was observed in the absence of DTT. Consequently, all studies reported were performed in the presence of $20 \mathrm{mM}$ DTT. In the first experiment, $5^{\prime}$-monodeiodination of $\mathrm{T}_{4}$ was assessed in microsomes from a pregnant doe and in four different concentrations of pooled microsomes from the corresponding fetuses. Values for the $\mathrm{K}_{\mathrm{m}}$ of the enzyme in the fetal microsomes agreed quite well with one another (mean, 5.7 $\pm 2.7 \times 10^{-5} \mathrm{M}$; range, 2.0 to $8.0 \times 10^{-5}$ ), and were much higher than the $\mathrm{K}_{\mathrm{m}}$ of the enzyme in maternal microsomes, $5.8 \times 10^{-6} \mathrm{M}$ (Fig. 3). Though not strictly proportional to microsomal protein concentration, observed values for the $\mathrm{V}_{\max }$ of the reaction increased with increasing microsomal concentration, as would be expected. Thus, in specimens containing approximately 1, 2, 3, and $4 \mathrm{mg}$ of microsomal protein, values for the $\mathrm{V}_{\max }$ (nmoles per $\mathrm{mg}$ protein per $\mathrm{hr}$ ) were $0.62,0.83,1.05$, and 0.93 , respectively.

The second experiment, in which enzyme kinetics were concomitantly assessed in microsomes from the livers of two does and their corresponding fetuses, confirmed the principal findings of the first. Values of the $K_{m}$ of the two samples of maternal enzyme agreed quite closely with one another, as did values for the $\mathrm{K}_{\mathrm{m}}$ of the two samples of fetal enzyme, but the mean maternal $K_{m}(7.7$ $\times^{-5}$ ) was much lower than the corresponding mean for the fetal enzyme $\left(6.0 \times 10^{-5}\right)$ (Fig. 4$)$.

For the three sets of maternal and fetal enzyme examined concomitantly, values for the $\mathrm{K}_{\mathrm{m}}$ of the maternal enzyme averaged $7.1 \pm 1.3 \times 10^{-6} \mathrm{M}$ and for the fetal enzyme, $5.9 \pm 2.0 \times 10^{-5}$ $\mathrm{M}(P<0.05)$.

$$
\begin{gathered}
\text { Kinetics of } T_{3} \text { generation from } T_{4} \text { in fetal and maternal } \\
\text { rabbit liver microsomes }
\end{gathered}
$$

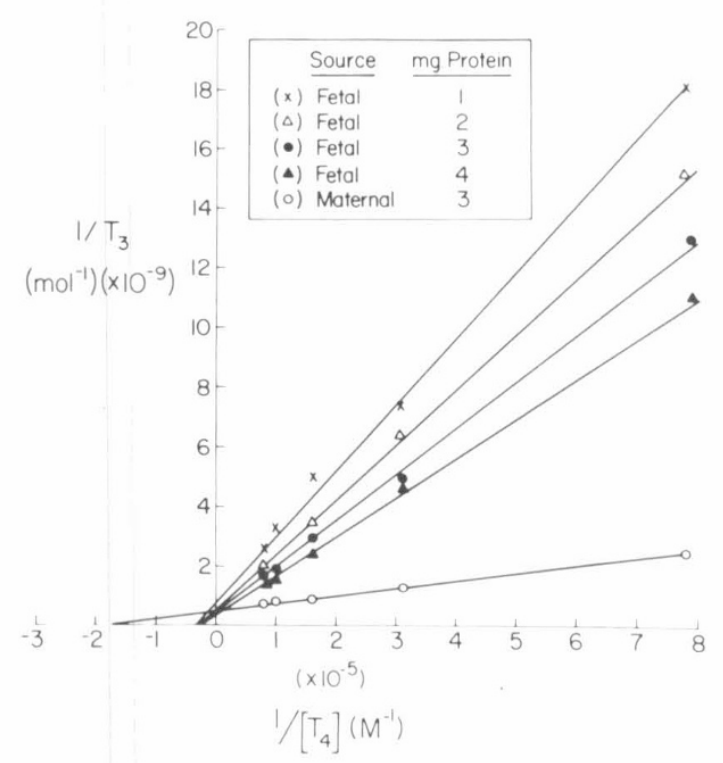

Fig. 3. Kinetics of $T_{3}$-neogenesis in liver microsomes from a pregnant rabbit and from four concentrations of microsomes from a pool of the corresponding fetal livers. Specimens were incubated in $0.15 \mathrm{M}$ phosphate buffer ( $\mathrm{pH} \mathrm{7.4)}$ in air at $37^{\circ} \mathrm{C}$ for $90 \mathrm{~min}$. Values for $\mathrm{K}_{\mathrm{m}}$ in maternal and fetal specimens were $5.8 \times 10^{-6}$ and $5.7 \times 10^{-5} \mathrm{M}$, respectively. 
Kinetics of $T_{3}$ generation from $T_{4}$ in fetal and maternal rabbit liver microsomes

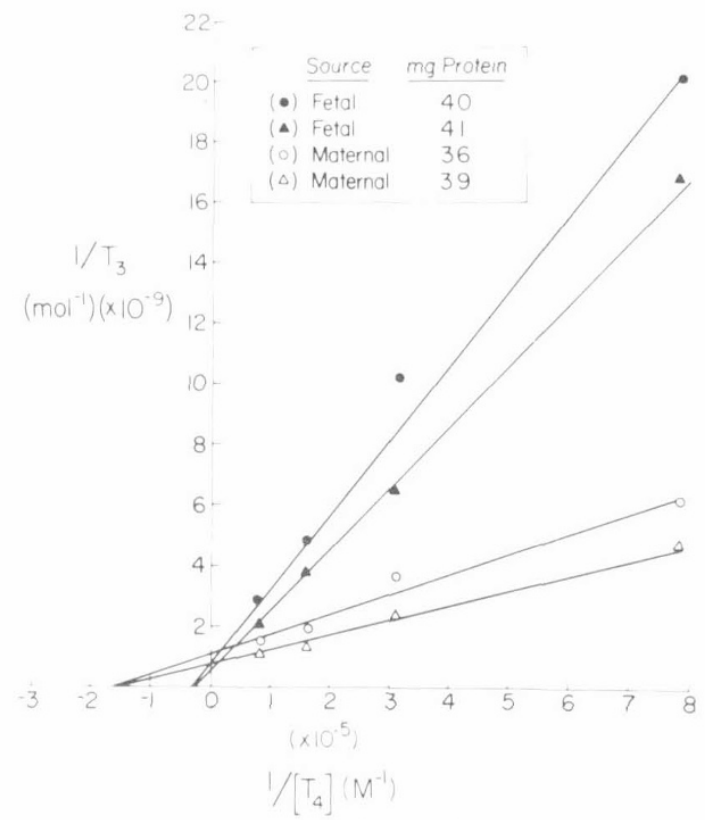

Fig. 4. A comparison of the kinetics of $\mathrm{T}_{3}$-neogenesis by hepatic microsomes in two fetal-maternal pairs. Open and closed symbols of each type represent data from one fetal-maternal pair. Incubation conditions identical to those described in Figure 3. Values for the mean $\mathrm{K}_{\mathrm{m}}$ in maternal and fetal specimens were $6.0 \times 10^{-5}$ and $7.7 \times 10^{-6} \mathrm{M}$, respectively.

\section{DISCUSSION}

It is well established that the enzymatic process in peripheral tissues by which $T_{4}$ undergoes $5^{\prime}$-monodeiodination to yield the more active hormone $T_{3}$ occurs overall at a far slower rate during fetal life than it does during the postnatal period and during maturity $(9,12,21,22,25)$. Evidence to this point has been obtained from measurements of $\mathrm{T}_{3}$ concentrations in serum from actual measurements of $T_{3}$ production rates in vivo $(9,18,19)$ and from studies in which rates of $\mathrm{T}_{3}$-neogenesis have been assessed in vitro in various tissues $(4,14,15,25)$, particularly liver. This lower level of $\mathrm{T}_{3}$-neogenesis during fetal life has been found in man ( 8 , $23)$, sheep $(18,19,21,22)$, and rats $(14,15)$, but is not confined to mammalian species, as it has also been observed in the liver of immature chick embryos (4). Despite the uniformity with which a lesser rate of $\mathrm{T}_{3}$-neogenesis in the fetus than in the adult has been found, there is no agreement concerning the cellular mechanisms responsible for this difference. Some studies suggest that it is due to a relative deficiency of reduced sulfhydryl groups (25), known cofactors of the $5^{\prime}$-monodeiodinase for $\mathrm{T}_{4}(1-3,6,7)$, whereas others suggest that lower concentrations of both the enzyme and cofactor are responsible (14).

Our studies shed additional light on this problem, indicating that in the rabbit fetus an abnormality of the enzyme, and to a lesser extent, a deficiency of cofactor are responsible for the impaired $\mathrm{T}_{3}$-neogenesis seen in fetal liver. This conclusion is based on several lines of evidence provided by the differing types of experiments performed. In unenriched whole homogenates of liver, fetal tissues displayed negligible formation of $T_{3}$ from $T_{4}$, whereas maternal tissues were active. Moreover, addition of DTT, a sulfhydryl stabilizer and known stimulant of $\mathrm{T}_{3}$-neogenesis ( 1 , $2,5-7)$, produced its expected effect in maternal liver, but had no significant stimulatory action in fetal liver. These findings pointed to an abnormality in the enzyme as the major factor responsible for the lesser fetal $\mathrm{T}_{3}$-neogenesis.

Studies in which maternal or fetal liver microsomes were variously mixed with either maternal or fetal liver microsomes pro- vided even stronger evidence of an enzymatic abnormality in the fetus. In samples containing fetal microsomes, $\mathrm{T}_{3}$-neogenesis was minimal, irrespective of whether fetal or maternal cytosol had been added, and consistently higher values of $T_{3}$-neogenesis were seen when maternal microsomes were used instead. Moreover, specimens containing maternal microsomes displayed significant stimulation of $\mathrm{T}_{3}$-neogenesis by either DTT or maternal cytosol, whereas those containing fetal microsomes did not. These findings serve to emphasize the intrinsic difference between the 5 '-monodeiodinases for $\mathrm{T}_{4}$ of maternal and fetal liver.

Reconstitution experiments (3) also provided evidence of a deficiency of cofactor, presumed to be sulfhydryl in nature, in the fetal cytosol. Thus, in the absence of DTT, $\mathrm{T}_{3}$-neogenesis by maternal microsomes in specimens containing maternal cytosol was far greater than in specimens containing fetal cytosol, but addition of DTT abolished the difference between them.

The most direct evidence of an abnormality in the fetal enzyme, relative to that in the adult, was provided by the kinetic studies that were performed. Owing to the low activity of the microsomal preparations from either maternal or fetal liver suspended in buffer alone, we were unable to compare the properties of the maternal and fetal enzymes in the absence of DTT. As a consequence, we were also unable to determine whether the increase in $\mathrm{T}_{3}$ formation from $\mathrm{T}_{4}$ produced by DTT in whole homogenates of maternal liver was due to an effect on the $V_{\max }$ or the $K_{m}$ of the reaction. We can only remark that, in the presence of ample DTT, the fetal enzyme displayed a much higher $\mathrm{K}_{\mathrm{m}}$ than the maternal enzyme did.

Considered together, our data and the conclusions that they lead to agree in some respects, but disagree in others, with those of other workers. All major studies indicate that a relative deficiency of sulfhydryl cofactor plays a role in the lesser $T_{3}$-neogenesis displayed by fetal liver in vitro $(7,14,25)$. However, Chopra (7), as well as Wu et al. (25), conclude that this is the sole abnormality; in their studies, the lesser $\mathrm{T}_{3}$-neogenesis in fetal liver was not seen when both fetal and maternal specimens were enriched with DTT $(7,25)$. On the other hand, Harris et al. (14) who found evidence of a decreased nonprotein-SH concentration in the fetal rat liver, saw some enhancement, but not normalization, of the activity of fetal liver homogenates upon addition of DTT. Their findings with respect to $T_{3}$-neogenesis resemble our own.

Opinions regarding the enzyme itself are also variable. Wu et al. (25), from kinetic studies in whole liver homogenates, concluded that values of the $\mathrm{K}_{\mathrm{m}}$ of the maternal and fetal hepatic enzymes in the sheep were the same, but that the $V_{\max }$ of $\mathrm{T}_{3^{-}}$ neogenesis was lower in the latter. Because DTT corrected the deficient $T_{3}$-neogenesis seen in fetal samples, one would necessarily infer that it had done so by increasing the $\mathrm{V}_{\max }$. Harris et al. (14) did not perform kinetic studies, but concluded from their failure to normalize $T_{3}$-neogenesis by the addition of DTT that the fetal abnormality is a decreased enzyme concentration. Our own data permit no conclusion about the concentration of the fetal enzyme. Instead, they demonstrate quite conclusively, we believe, that in the fetal rabbit the hepatic $5^{\prime}$-deiodinase for $\mathrm{T}_{4}$ is less active than the maternal enzyme in the presence of ample cofactor and that the cause of this lesser activity is a lower affinity of the enzyme for the substrate. A similar explanation could account for the findings of Harris and his colleagues. An abnormal, SH-unresponsive enzyme would also explain the results obtained in the chick embryo (4). Here, $\mathrm{T}_{3}$-neogenesis in homogenates of immature embryo liver was found to be negligible and was not increased by addition of DTT. In contrast, during spontaneous maturation, or after injection into the egg of hydrocortisone, hepatic $\mathrm{T}_{3}$-neogenesis in vitro was more active and was briskly responsive to the addition of DTT.

The suggestion that the enzymes that convert $T_{4}$ to $T_{3}$ in fetal and maternal, or immature and mature, rabbit liver are intrinsically different from one another has ample precedent in the case of other enzymes. For example, differing isozymes in fetal and 
maternal tissues have been found in the case of lactic dehydrogenase (11), pyruvate kinase (17), aldolase (11), and arginase (16), and enzymic differentiation occurs in the course of perinatal development (13).

In the present studies, livers were obtained from rabbit fetuses that were only 1 or 2 days before term. To our surprise, the abnormalities in hepatic $\mathrm{T}_{3}$-neogenesis seen in these fetuses persisted for 2 wk after birth (24). In the light of the generally low developmental level at which the rabbit is born, this would suggest that it is the state of maturation, and not birth itself, that determines the state of the $T_{3}$-generating mechanism.

\section{REFERENCES AND NOTES}

I. Balsam. A., and Ingbar, S. H.: The influence of fasting, diabetes, and several pharmacological agents on the pathways of thyroxine metabolism in rat liver. J. Clin. Invest., 62: 415 (1978).

2. Balsam. A., and Ingbar, S. H.: Observations on the factors that control the generation of triiodothyronine from thyroxine in the rat liver and the nature of the defect induced by fasting. J. Clin. Invest., 53: 1145 (1979).

3. Balsam. A., Sexton, F., and Ingbar, S. H.: On the mechanism of impaired in vitro generation of $3,5,3^{\prime}$-triiodothyronine from thyroxine in the livers of hypothyroid rats. Endocrinology, 105: 1115 (1979).

4. Borges, M., LaBourene, J., and Ingbar, S. H.: Changes in hepatic iodothyronine metabolism during ontogeny of the chick embryo. Endocrinology, 107: 1751 (1980).

5. Chiraseveenuprapund, P.. Buergi, U., Goswami. A.. and Rosenberg. I. N. Conversion of $\mathrm{L}$-thyroxine to triiodothyronine in rat kidney homogenate. Endocrinology, 102: 612 (1978)

6. Chopra, I. J.: A study of extrathyroidal conversion of thyroxine $\left(\mathrm{T}_{4}\right)$ to $3,3^{\prime}, 5^{\prime}$ triiodothyronine $\left(\mathrm{T}_{3}\right)$ in vitro. Endocrinology, 1: 453 (1977).

7. Chopra, J. J.: Sulfhydryl groups and the monodeiodination of thyroxine to triiodothyronine. Science (Wash. D. C.), 199: 904 (1978).

8. Chopra. I. S., and Crandall, B. F.: Thyroid hormones and thyrotropin in amniotic fluid. N. Engl. J. Med., 293: 740 (1975).

9. Chopra. I. J., Sack, J., and Fisher, D. A.: 3,3',5'-Triiodothyronine (reverse $T_{3}$ ) and triiodothyronine $\left(\mathrm{T}_{3}\right)$ in fetal and adult sheep: studies of metabolic clearance rates, production rates, serum binding, and thyroidal content relative to thyroxine. Endocrinology, 97: 1080 (1975).

10. Dunnett. C. W.: Multiple comparisons. In: J. W. McArthur, T. Colton: Statistics in Endocrinology. Vol. 1, p. 86 (MIT Press, Cambridge, MA, 1970).

11. Farron, F.. Hsu, H. H. T., and Knox, W. E.: Fetal-type isoenzymes in hepatic and nonhepatic rat tumors. Cancer Res., 32: 302 (1972).

12. Fisher, D. A., and Sack, J.: Thyroid function in the fetus: thyroid hormone metabolism in amniotic fluid of man and sheep. In: D. A. Fisher and G. N.

Copyright (c) 1981 International Pediatric Research Foundation, Inc. 0031-3998/81/1508-1123\$02.00/0
Burrow: Perinatal Thyroid Physiology and Disease. (Raven Press, New York. 1975).

13. Greengard. O.: Enzymic differentiation in mammalian liver. Science (Wash. D. C.), 163: 891 (1969).

14. Harris, A., Fang, S., Hinerfeld, L., Braverman, L., and Vagenakis, A.: The role of sulfhydryl groups on the impaired hepatic 3'3,5-triiodothyronine generation from thyroxine in the hypothyroid, starved, fetal and neonatal rodent. J. Clin. Invest.. 63: 516 (1979).

15. Harris, A. R. C., Fang, S., Prosky, J., Braverman, L., and Vagenakis, A.: Decreased outer ring monodeiodination of $T_{4}$ and reverse $T_{4}$ by the fetal and neonatal rat. Endocrinology, 3: 2216 (1978).

16. Herzfeld, A. Rosenoer, V. M., and Raper, S. M.: Elutamate dehydrogenase. alanine aminotransferase, thymidine kinase, and arginase in fetal and adult human and rat liver. Pediatr. Res.. 10: 960 (1976).

17. Ibsen, K. H. Interrelationships and functions of the pyruvate kinase isozymes and their variant forms: a review. Cancer Res., 37: 341 (1977).

18. Klein, A. H., and Fisher, D. A.: The prenatal triodothyronine ( $\left.T_{3}\right)$ surge in the fetal sheep. Clin. Res., 26: 199A (1978).

19. Klein. A. H., Oddie, T. H., and Fisher, D. A.: Effect of parturition on serum iodothyronine concentrations in fetal sheep. Endocrinology, 103: 1453 (1978).

20. Lowry, O. H., Rosebrough, N. J., Farr, A. L., and Randall, R. J.: Protein measurement with the Folin phenol reagent. J. Biol. Chem.. 193: 265 (1951).

21. Nathaniels. P. W., Silver, M., and Comline, R. S.: Plasma triiodothyronin concentration in the fetal and newborn lamb. J. Endocrinology, 58: 683 (1973).

22. Sack. J., Lam, R. W.. and Fisher, D. A.: Thyroid hormone metabolism in aminotic and allantoic fluids of the sheep. Pediatr. Res., 9: 837 (1975).

23. Sack, J., Fisher, D. A. Hobel, C. S., and Lam. R. W.: Thyroxine in human amniotic fluid. J. Pediatr., 87: 364 (1975),

24. Segall-Blank, M.: Unpublished data.

25. Wu, S. Y., Klein. A. H.. Chopra. I. J.. and Fisher. D. A.: Alterations in tissue thyroxine-5'-monodeiodinating activity in perinatal period. Endocrinology. 103: 235 (1978).

26. The materials used were purchased from the following commercial sources: (1) Phenolic ring ${ }^{125} \mathrm{I}_{-} \mathrm{T}_{4}, 60$ to $70 \mu \mathrm{Ci} / \mu \mathrm{g}$, and ${ }^{125} \mathrm{I}-\mathrm{T}_{3}, 60$ to $75 \mu \mathrm{Ci} / \mu \mathrm{g}$, from Abbott Laboratories, North Chicago, IL. Crystalline $T_{4}$ and DTT from Sigma Chemical Co., St. Louis, MO.

27. Presented in part at the Fifty-fourth Annual Meeting of the American Thyroid Association. September 13-16, 1978, Portland, OR

28. The authors would like to thank Dr. John Torday and Michael Epstein, Children's Hospital Medical Center, Boston, MA, who kindly supplied animals and advice. Thanks also to Franklin Sexton. Beth Israel Hospital, Boston, MA, for his excellent technical assistance.

29. Requests for reprints should be addressed to: Dr. Sidney H. Ingbar, Beth Israel Hospital, 330 Brookline Avenue, Boston, MA 02215 (USA).

30. This research was supported in part by Grant AM-18416 from the National Institute of Arthritis. Metabolism, and Digestive Diseases, National Institute of Health, Bethesda. MD.

31. Received for publication September 26, 1980.

32. Accepted for publication February 2, 1981. 